Ius Matrimoniale 32 (2021) $\mathrm{nr} 1$

ISSN 1429-3803; e-ISSN 2353-8120

DOI: http://doi.org/10.21697/im.2021.32.1.05
Artykuł jest udostępniany na zasadach licencji Creative Commons (CC BY-ND 4.0 Międzynarodowe) https://creativecommons.org/licenses/by-nd/4.0/deed.pl

open 2 access (cc)

\title{
Osobowość niedojrzała a zdolność do wyrażenia zgody małżeńskiej. Wpływ rodziny pochodzenia na kształtowanie dojrzałości osoby
}

\section{Immature personality and ability to express marital consent. The influence of the family of origin on shaping the maturity of a person}

\author{
Emilia Zyskowska \\ Sąd Metropolitalny Warszawski \\ e-mail:em.zyskowska@gmail.com
}

Streszczenie: Wiele spraw o stwierdzenie nieważności małżeństwa jest prowadzonych z tytułu niezdolności do podjęcia istotnych obowiązków małżeńskich z przyczyn natury psychicznej (kan. 1095 n. 3 KPK/83). W znacznej części przypadków małżeństwo zostaje uznane za nieważne z powodu niedojrzałej osobowości jednej lub obu stron, która sprawia, że nupturienci od samego początku nie są w stanie podjąć podstawowych obowiązków małżeńskich. Każdy przypadek powinien zostać jednak rozpatrzony bardzo ostrożnie, ponieważ punkt osiągnięcia dojrzałości jest jedynie umowny, a kształtowanie osobowości trwa całe życie.

Artykuł ma na celu omówienie możliwych uwarunkowań osobowości niedojrzałej, kształtowanej przez rodzinę pochodzenia. Rodzina kształtuje podstawowe zręby osobowości dziecka, m.in. system postaw i potrzeb, sposoby ich zaspokajania oraz niezwykle ważny mechanizm samooceny. Dzieci wychowujące się w rodzinach dysfunkcyjnych podlegają wpływowi stresogennych i patogennych czynników, stanowiących źródło głębokich urazów psychicznych, powodujących zmiany w strukturze osobowości oraz problemy emocjonalne i zaburzenia w zachowaniu.

Słowa kluczowe: osobowość, dojrzałość, rodzina pochodzenia, zgoda małżeńska

Abstract: Many cases of the nullity of marriage are conducted due to the inability to undertake essential marriage duties of mental incapacity (can. 1095 n. 3 CIC/83). In a significant proportion of cases, the marriage is invalid because of the immature personality of one or both parties, which makes it impossible for the spouses to take on basic marriage duties from the beginning. However, each case should be considered very carefully because the point of reaching maturity is merely contractual, and the formation of a personality lasts a lifetime.

The article aims to discuss possible determinants of an immature personality shaped by the family of origin. The family shapes the basic frameworks of the child's personality, 
including a system of attitudes and needs, way of satisfying them and an extremely important mechanism of self-esteem. Children, who are raised in dysfunctional families, are influenced of stressogenic and pathogenic factors, which are the source of psychological trauma, causing changes in the personality structure as well as emotional and behavioral problems.

Keywords: personality, maturity, family of origin, marital consent

Treść: Wstęp. 1. Kryteria dojrzałości osobowości. 1.1. Osobowość dojrzała. 1.2. Osobowość niedojrzała w małżeństwie. 2. Rodzina pochodzenia. 2.1. Rodzina chaotyczna. 2.2. Rodzina władzy. 2.3. Rodzina nadopiekuńcza. 2.4. Rodzina uwikłana. 2.5. Rodzina prawidłowa. 3. Zakończenie. 4. Bibliografia.

\section{Wstęp}

W Polsce w procesach o stwierdzenie nieważności małżeństwa najczęściej aplikowanymi tytułami są tytuły dotyczące niezdolności konsensualnej (kan. 1095, n. 1-3 KPK/83) ${ }^{1}$. Według przyjętych rozwiązań systemowych nupturient $\mathrm{w}$ chwili zawarcia małżeństwa powinien być psychicznie zdolny do zawarcia związku. W publikacjach poświęconych tej tematyce wskazuje się na różne anomalie psychiczne uniemożliwiające uzyskanie tego stanu ${ }^{2}$. Wśród nich wymienia się m.in. osobowość niedojrzałą. Należy jednak zauważyć, iż zgodnie z doktryną, niezdolność konsensualna kontrahenta do ważnego wyrażenia zgody małżeńskiej występuje jedynie w przypadkach poważnych, tzn. w sytuacjach, gdy zostanie ograniczona wolność decyzyjna podmiotu proporcjonalna do zawarcia małżeństwa ${ }^{3}$.

W wielu przypadkach osobowość niedojrzała ma swoją genezę w rodzinie patologicznej albo wadliwym wychowaniu. Rodzina

1 Por. P. Malecha, Polski wymiar sprawiedliwości widziany przez pryzmat Sygnatury Apostolskiej, w: T. RozkRUT (red.), Orzecznictwo rotalne w praktyce sądowej Kościoła, Tarnów 2010, s. 36-38.

2 Por. R. Sobański, Wyrok Sądu Metropolitalnego w Katowicach z 29.12.2005 ztytułu niezdolności - z racji psychicznych - powoda do podjęcia istotnych obowiązków małżeńskich, Ius Matrimoniale 11 (2006), s. 180-182.

3 Por. G. Leszczyński, Niedojrzałość emocjonalna a wykluczenie dobra małżonków, Ius Matrimoniale 7 (2002), s. 87. 
bowiem stanowi podstawowe środowisko wychowawcze dla dziecka, dlatego przez długi czas wywiera znaczący wpływ na kształtowanie jego osobowości. Należy też spostrzec, iż oddziaływanie rodziców na swe potomstwo odnosi się do szerokiego spektrum egzystencjalnych sfer. W literaturze przedmiotu pisze się, iż oddziałują oni na rozwój funkcji poznawczych dziecka, co przekłada się później na jego osiągnięcia szkolne, na tworzenie równowagi emocjonalnej i dojrzałości społecznej, budowanie obrazu własnej osoby, stosunek do grupy rówieśniczej, w końcu na wywiązywanie się z ról rodzicielskich i zawodowych w dorosłym życiư ${ }^{4}$.

Jak wykazał R. Sztychmiler, w wielu wyrokach polskich trybunałów kościelnych stwierdzono nieważność małżeństwa $\mathrm{z}$ powodu występowania osobowości niedojrzałej; bardziej precyzyjnie, z jej wpływu na niezdolność konsensualną do zawarcia małżeństwa W psychologii zagadnienie osobowości niedojrzałej zaliczane jest do najtrudniejszych, dlatego w wielu dyskusjach jest ono podejmowane.

W niniejszym opracowaniu zostanie podjęty namysł nad kwestią niedojrzałej osobowości generowanej niewłaściwym funkcjonowanem rodziny pochodzenia, co może znaleźć przełożenie w niezdolności konsensualnej do zawarcia małżeństwa.

\section{Kryteria dojrzałości osobowości}

Określone w podtytule zagadnienie zostanie podjęte w dwóch wątkach. Najpierw zostanie ukazana kwestia osobowości dojrzałej, która stanie się kontekstem do rozważenia problemu osobowości niedojrzałej w małżeństwie.

\footnotetext{
4 Por. J. Stachyra, Wpływ rodziny na kształtowanie się osobowości dziecka, Sympozjum 2 (2000), s. 85.

5 Por. R. Sztychmiler, Znaczenie osobowości kandydata do małżństwa w świetle obowiązującego prawa kanonicznego, Prawo Kanoniczne 40 (1997), s. 201.
} 


\subsection{Osobowość dojrzała}

Celnie zauważył G. Leszczyński, iż w praktyce nie da się jednoznacznie określić momentu, w którym człowiek osiągnął stadium rozwoju osobowości, o której można by powiedzieć, że spotykamy się z pełnią dojrzałości. Jest tak dlatego, zauważa kanonista, ponieważ osobowość podlega procesowi kształtowania przez całe życie; moment osiągnięcia pewnego stopnia dojrzałości jest więc sprawą umowną ${ }^{6}$.

W literaturze przedmiotu wskazuje się, że osiągnięcie dojrzałości psychologicznej jest punktem rozwoju, w którym dana osoba jest świadoma i wolna w działaniu do tego stopnia, że potrafi dostosować się zarówno do swoich ideałów, jak i otaczającej ją rzeczywistości. Stan, o którym mowa, przejawia się m.in. w tym, że z jednej strony posiada ona stabilną hierarchię wartości, z drugiej zaś jest zdolna do akceptacji samego siebie. Poza tym dojrzałość tą wiąże się również $\mathrm{z}$ umiejętnością mierzenia się $\mathrm{z}$ wewnętrznymi i zewnętrznymi trudnościami. Podkreśla się też, iż w pojęciu dojrzałej osobowości znajdują się także takie faktory, jak: umiejętność komunikacji interpersonalnej z drugą osobą, zdolność do nazywania i ekspresji własnych uczuć i emocji, zdolność akceptowania drugiej osoby bez stawiania jej warunków, odrzucenie dominującego wpływu mechanizmów obronnych fałszujących obiektywną wizję rzeczywistości

6 Por. G. Leszczyński, Niedojrzałość emocjonalna..., s. 90-91.

7 Por. W. Prężyna, Problem psychologicznych kryteriów niezdolności do podjęcia i wypetnienia zobowiązań małżeńskich, w: J. KRUkowski (red.), Kościół i Prawo, t. 6, Lublin 1988, s. 104; A. GoŁęBIowsKA, Osobowość niedojrzała jako podstawa orzeczenia nieważności małżeństwa w świetle wyroków Roty Rzymskiej i trybunałów kościelnych, Prawo Kanoniczne 55 (2012), s. 59-61; A. MendoncA, The Effects of Personality Disorders on Matrimonial Consent, Studia Canonica 21 (1987), s. 71-77; R.W. GuIRY, Immaturity, Maturity, and Christian Marriage, Studia Canonica 25 (1991), s. 111-113. 


\subsection{Osobowość niedojrzała w małżeństwie}

W kontekście instytucji małżeństwa kanonicznego szczególnie istotna jest niedojrzałość w obszarze emocjonalnym i społecznym ${ }^{8}$. Przy tym należy podkreślić, iż dla niedojrzałości emocjonalnej najbardziej charakterystyczne są słabo zróżnicowane i nieadekwatne reakcje emocjonalne. Poza tym, taka osoba przejawia nasilony egoizm i egocentryzm, brak zrównoważenia emocjonalnego oraz niską odporność na stres. Niedojrzałość społeczna z kolei uwidacznia się przede wszystkim w takich zachowaniach, jak: niski poziom aktywności społecznej, obniżona samodzielność, nieumiejętność podejmowania wysiłku prowadzącego do realizacji odległego celu, którym w tym wypadku jest małżeństwo'.

\section{Rodzina pochodzenia}

Rodzina troszczy się o rozwój dziecka poprzez otaczanie go indywidualną opieką i zaspokojenie jego potrzeb psychicznych, co stanowi jedno z jej najważniejszych zadań ${ }^{10}$. Maria Ziemska wskazuje na podstawowe potrzeby, których zaspokojenie daje także możliwość zaspokojenia pozostałych. Pierwszą z nich jest potrzeba kontaktu emocjonalnego. Dla osiągnięcia, jej zdaniem, prawidłowego rozwoju psychicznego i społecznego, dziecko musi odczuwać akceptację rodziców, bez względu na to czy w pełni spełnia ich oczekiwania. Wzrastając w poczuciu życzliwości i serdeczności, czuje się bezpiecznie i pewnie. Tym sposobem otrzymuje zaspokojenie kolejnej potrzeby - potrzeby bezpieczeństwa. Konsekwencją jej utraty staje się zerwanie kontaktu emocjonalnego z najbliższymi. Potrzeba kontaktu społecznego zaspokajana jest przez czynną obecność rodziców w życiu dziecka. Jeśli odczuwa ono zainteresowanie ze strony rodziców

\footnotetext{
8 Por. A. Mendonca, The Effects of Personality..., s. 77-82.

9 Por. K. Graczy , Dowodzenie nieważności..., s. 263; A. GoŁĘBIowska, Osobowość niedojrzała..., s. 62-63.

10 Por. J. Stachyra, Wplyw rodziny..., s. 87.
} 
tym, co robi, a jednocześnie samo ma możliwość obserwowania tego, co robią rodzice, wówczas wykształca w sobie umiejętność współdziałania. Kolejną z potrzeb jest potrzeba samourzeczywistniania. Rodzice winni dawać dziecku swobodę działania, różną w zależności od wieku, a także dostarczać odpowiednich bodźców rozwojowych, stwarzając dziecku szansę rozwoju jako jednostki indywidualnej. Przy tym, zauważa autorka, udzielana swoboda nie może być jednak równoznaczna z brakiem kontroli czy opieki. Prawidłowe, w jej opinii, oddziaływania w tym względzie sprzyjają wykształceniu się u dziecka samodzielności, aktywności i odpowiedzialności. Ostatnią z potrzeb jest potrzeba szacunku, zwana też potrzebą uznania społecznego, wynikająca z godności człowieka. Dziecko nie może być lekceważone, poniżane i krytykowane. Na podstawie sądów innych osób, w szczególności rodziców, tworzy bowiem ono swoją samoocenę. Jeśli czuje się kochane i akceptowane, wówczas odczuwa wiarę w siebie mając zarazem adekwatną i zdrową samoocenę; jeśli zaś rodzice dają jemu odczuć, że nie spełnia ich oczekiwań, wtenczas szybko wyrabia w sobie zaniżoną samoocenę i brak wiary we własne umiejętności ${ }^{11}$.

W literaturze przedmiotu podkreśla się, iż istotne znaczenie dla rozwoju osobowości ma także identyfikacja z rodzicami. Pierwsze wzory osobowe są dostarczane dziecku przez rodziców. Chociaż największe oddziaływanie $\mathrm{z}$ ich strony dotyczy przede wszystkim okresu wczesnego dzieciństwa, to ślady w funkcjonowaniu danej osoby zauważalne są nawet po osiągnięciu dorosłości. Identyfikacja z rodzicami pozwala na przyjęcie pewnych wzorów zachowania i podejmowania zadań związanych z pełnionymi różnorodnymi rolami społecznymi. Jeśli otrzymane wzorce są pozytywne, wtedy dziecko z łatwością przechodzi proces socjalizacji. Za najwłaściwsze uznaje się postępowanie świadczące o akceptacji dziecka i zainteresowaniu nim. Rodzice uczą je w ten sposób przyjaznej postawy wobec otoczenia, chęci do współdziałania i angażowania się w sprawy innych ${ }^{12}$.

11 Por. M. Ziemska, Postawy rodzicielskie, Warszawa 1973, s. 26-31; J. Stachyra, Wpływ rodziny..., s. 87-89.

12 Por. TAмże, s. 89-92. 
W kształtowaniu osobowości dziecka nie można również abstrahować od atmosfery rodzinnej oraz zachodzących w niej stosunków i relacji interpersonalnych. Atmosferę rodzinną bowiem tworzy charakter wzajemnych stosunków pomiędzy członkami, a także ich klimat uczuciowy towarzyszący ich relacjom. Z pewnością ważne jest, aby ta atmosfera cechowała się ciepłem i przyjaźnią; jednak zwraca się uwagę też na to, aby ona odznaczała się względną stałością. Jak wynika z badań, częste zmiany w atmosferze rodzinnej bardziej zaburzają poczucie bezpieczeństwa dziecka, niż niekorzystna atmosfera utrzymująca się na stałym poziomie ${ }^{13}$.

Poza tym w publikacjach poświęconych tej tematyce eksponuje się również postawy rodzicielskie. Termin „postawa” definiowany jest jako „tendencja do zachowania się w specyficzny sposób wobec jakiejś osoby, sytuacji czy problemu, czyli ogólnie mówiąc przedmiotu, na który jest skierowana"14. Kształtowanie postaw rodzicielskich zależy od wielu faktorów: wyniesionego z domu rodzinnego doświadczenia postaw, oczekiwań związanych z dzieckiem, stopnia satysfakcji z pożycia małżeńskiego, wpływu innych bliskich osób, wreszcie osobowości samych rodziców ${ }^{15}$. Relacje wewnątrzrodzinne kształtowane przede wszystkim przez postawy rodzicielskie, ale także pewna hierarchia, zespół norm i zasad, określone cele, sposoby zaspokajania potrzeb poszczególnych jej członków oraz realizacja podstawowych zadań społecznych, tworzą pewien system, który jest odpowiedzialny za wzorce interakcji zachodzących między członkami rodziny. Koncepcja systemu rodzinnego zakłada, że relacje wewnątrzrodzinne mają na tyle znaczący wpływ na funkcjonowanie poszczególnych członków rodziny, że próba zrozumienia czy prognozowania zachowania danej jednostki jest nieadekwatna bez uwzględnienia kontekstu, na który składają się pozostali członkowie rodziny ${ }^{16}$.

\footnotetext{
13 Por. TAmŻe, s. 92.

14 Por. M. Ziemska, Postawy rodzicielskie, s. 31-32.

15 Por. TAmże, s. 32-34.

16 Por. V. Michaelson, W. Pickett, N. King, C. Davison, Testing the theory of holism: A study offamily systems and adolescent health, Preventive Medicine Reports 4 (2016), 313-316.
} 
W literaturze przedmiotu wyróżnia się kilka typologii systemów rodzinnych. Jednym z nich jest typologia wypracowana przez Davida Fielda, uwzględniająca w charakterystyce każdego systemu relację małżeńską rodziców, postawy rodzicielskie, dynamikę rodzinną, wpływ wartości duchowych i religijnych oraz funkcjonowanie dzieci w okresie dorosłości. Dla D. Fielda podstawą w charakterystyce struktury rodziny są interakcje między jej członkami, w których ważny jest przede wszystkim sposób odnoszenia się do siebie i reagowania. Przynależność do systemu rodzinnego kształtuje obraz siebie dzieci, pomaga im nauczyć się odpowiedzialności, afirmacji wartości oraz wzorców relacyjnych. Głównym celem wychowawczym, według badacza, stawianym sobie przez rodziców winno być przystosowanie dziecka do dorosłego życia w taki sposób, aby mogło ono zdobyć umiejętności niezbędne do prawidłowego funkcjonowania. Odpowiednio stymulowany rozwój dzieci ma za zadanie pomóc im odnaleźć prawidłową równowagę między potrzebą indywidualności, a potrzebą relacji z innymi ludźmi ${ }^{17}$.

D. Field wyodrębnił pięć typów rodzin: chaotyczny, władczy, prawidłowy, nadopiekuńczy oraz uwikłany. Za bazę takiej kwalifikacji uznał istniejące granice pomiędzy rodzicami a dziećmi ${ }^{18}$.

Poniżej przedstawimy charakterystykę poszczególnych systemów rodzinnych oraz ich wpływ na późniejsze funkcjonowanie osoby dorosłej.

\subsection{Rodzina chaotyczna}

Wyróżniającymi cechami rodziny chaotycznej jest jej zła organizacja i rozdarcie. Członkom rodziny brakuje bliskości emocjonalnej. Rodzice nie są wrażliwi na potrzeby dziecka; nie ma między nimi

\footnotetext{
17 Por. D. Field, Osobowości rodzinne. Zrozumienie korzeni swojej osobowości kluczem do zrozumienia siebie i innych, Warszawa 1999, s. 24-27, 28-29; M. RYś, Systemy rodzinne. Metody badań struktury rodziny pochodzenia i rodziny własnej, Warszawa 2004, s. 23-24.

18 Por. D. Field, Osobowości rodzinne..., s. 27-28.
} 
bliższych więzi. Pomiędzy małżonkami brakuje miłości, za to bardzo często dochodzi do kłótni. Postawy rodziców wobec dzieci cechuje brak konsekwencji. Duże znaczenie mają tu nastroje rodziców, co w szczególności znajduje przełożenie w stosowaniu środków dyscyplinarnych, które często okazują się nazbyt surowe w porównaniu do wagi przewinienia. Co więcej, kara ma także na celu poniżenie dziecka. Egzekwowanie posłuszeństwa często odbywa się także przy użyciu przemocy ${ }^{19}$.

Członkowie rodziny żyją niejako obok siebie, a rodzina jako taka właściwie nie istnieje. Dom jest traktowany jako hotel. Brakuje wspólnego spędzania czasu z członkami rodziny. Dzieci unikają spotkań $\mathrm{z}$ rówieśnikami w swoim domu rodzinnym, ponieważ są niepewne swoich stosunków z rodzicami i odczuwają brak stabilności emocjonalnej. Wszyscy członkowie takiej rodziny często są nieufni wobec osób z zewnątrz, nie podejmują z nimi współpracy i nie nawiązują prawidłowych relacji. Z reguły są dostrzegane, ale tylko wtedy, gdy jest to korzystne ${ }^{20}$.

Dzieci dorastające w takiej rodzinie zazwyczaj opuszczają ją przedwcześnie, pozostawiając za sobą nierozwiązane konflikty z rodzicami. Zdarza się, że podejmują działania mające przede wszystkim na celu ucieczkę; tendencja ta przejawia się we wczesnym zajściu w ciążę, popełnianiu przestępstw, wstąpieniu do wojska. Powroty do domu rodzinnego wynikają zwykle $\mathrm{z}$ poczucia obowiązku, a nie $\mathrm{z}$ emocjonalnej potrzeby. Funkcjonowanie w życiu dorosłym najczęściej związane jest $\mathrm{z}$ wysokim stopniem autonomii; równocześnie jednak pojawia się wiele problemów w relacjach interpersonalnych, przede wszystkim z powodu silnej potrzeby kontroli innych oraz nieumiejętności zaufania drugiej osobie. Osoba przebywająca w takim środowisku charakteryzuje się silnym egocentryzmem. Łatwo wpada

19 Por. TAmżE, s. 69-74; M. RYś, Odporność psychiczna osób wzrastających w różnych systemach rodzinnych, Warszawa 2016, s. 29-31.

20 Por. D. Field, Osobowości rodzinne..., s. 75-76. 
w gniew, a gdy jest sfrustrowana, od razu przechodzi do ataku, co w efekcie pogłębia jej dystans do innych ${ }^{21}$.

\subsection{Rodzina władzy}

Najbardziej charakterystyczną cechą rodziny władzy jest jej wyraźna struktura. Jedno z rodziców (najczęściej jest to ojciec) pełni rolę głowy rodziny, drugi pełni niejako funkcję pomocniczą. W systemie tym wypracowano jasno określone zadania i oczekiwania wobec każdego z jej członków. Zasady są przedkładane nad stosunki międzyludzkie. Dzieci znajdują się pod całkowitą władzą rodziców. Reguły postępowania stają się najczęściej jedyną płaszczyzną relacji. Miłość, o ile istnieje, wyrażana jest poprzez właściwe wypełnianie zadań. Rodzice okazują dzieciom niewielkie zainteresowanie. Komunikacja służy do przekazywania nakazów i poleceń ${ }^{22}$.

Taki sam sztywny i przejrzysty podział ról panuje między małżonkami, a ich styl życia cechuje surowość. Na zewnątrz nie okazują sobie uczuć; zazwyczaj nie spędzają czasu razem. Są kompetentni w swoich rolach i dobrze wypełniają związane z nimi obowiązki ${ }^{23}$.

Na postawę rodzicielską składa się system praw, nakazów i zakazów. Rodzice koncentrują się przede wszystkim na stawianiu wymagań oraz ich egzekwowaniu; nie posiadają umiejętności słuchania. Jeśli coś nie jest wykonane zgodnie z ich zaleceniami, wówczas natychmiast posuwają się do krytyki. Stawiane wymagania są bardzo wysokie, a błędy dziecka nie są tolerowane. Rodzice stoją na stanowisku, że dziecko wie, co i jak należy zrobić, więc do rzadkości należy udzielanie wskazówek. Osiągnięcia i postępy dziecka są traktowane jak coś oczywistego, więc nie uważają za zasadne udzielenie pochwały, natomiast nie szczędzą krytyki i koncentrowania się na tym, co można było wykonać lepiej. Taki sposób postępowania utrwala w dziecku przekonanie, że akceptację innych można osiągnąć tylko poprzez

\footnotetext{
21 Por. Tamże, s. 77-78; M. Ryś, Odporność psychiczna..., s. 29-31.

22 Por. D. Field, Osobowości rodzinne..., s. 42-45.

23 Por. M. Ryś, Odporność psychiczna..., s. 27-28.
} 
jak najlepsze wykonywanie swoich obowiązków, i że nie ma w tym miejsca na błędy ${ }^{24}$.

W stylu życia niektórych członków rodziny władzy może występować pewna dwoistość. Ze względu na to, że niepowodzenie czy porażka najczęściej spotykają się z surową karą, dzieci mogą posługiwać się kłamstwem, aby ukryć niekorzystne dla nich sytuacje. Rodzina władzy nie odczuwa potrzeby bliskich kontaktów ze światem zewnętrznym i dopasowywania się do panujących tam zasad, ponieważ zazwyczaj jej członkowie cechują się władczością i próbą dominacji nad innymi, poczuciem bycia lepszymi od nich ${ }^{25}$.

Podobnie jak w rodzinie chaotycznej, dzieci pragną szybko opuścić dom rodzinny i wycofać się z panujących tam relacji. Często jest to próba udowodnienia, że są w stanie samodzielnie poradzić sobie w życiu. Z uwagi na to, że były traktowane w sposób pozbawiony czułości, nie potrafią jej okazywać innym. Są silnymi indywidualistami, z tego powodu ciężko jest im wchodzić w relacje, ponieważ nie zostały nauczone współdziałania $z$ innymi. Zdarza się, że dzieci z rodziny władzy buntują się przeciwko rodzicom, poszukując miłości na zewnątrz, którą utożsamiają ze sferą fizyczną, co prowadzi do wczesnego rozpoczęcia życia seksualnego. Jeśli zawierają małżeństwo, to zazwyczaj z osobą bardziej zorientowaną na relacje, którą jednak starają się trzymać na dystans, co szybko prowadzi do poczucia niezrozumienia i odrzucenia ${ }^{26}$.

\subsection{Rodzina nadopiekuńcza}

W porównaniu do poprzednich typów rodzin, w rodzinie nadopiekuńczej na pierwszym miejscu stawiane są relacje interpersonalne. Największą wartość stanowi bezkonfliktowy styl życia, stąd nie porusza się kontrowersyjnych tematów; unika się też rozmów

\footnotetext{
24 Por. D. Field, Osobowości rodzinne..., s. 47-48.

25 Por. TAmże, s. 50-51.

26 Por. TAmżE, s. 52-53; I. PrZy Byє, Obraz matki i ojca a identyfikacja adolescentów z rodzicami, Roczniki Socjologii Rodziny 17 (2016), s. 50.
} 
o problemach rodzinnych. Kultywowane są tradycje, chętnie podkreśla się wzajemną lojalność i odpowiedzialność. Plany rodziny są najczęściej determinowane potrzebami dzieci. Rodzice skupiają na dzieciach zbyt mocno swoją uwagę, przez co nie posiadają u nich autorytetu $^{27}$. Pomiędzy rodzicami a dziećmi nie zostają zachowane żadne granice, co w znaczący sposób utrudnia osiągnięcie niezależności. Dzieci otrzymują konieczne wsparcie i troskę ze strony rodziców, spełniane są ich oczekiwania i zaspokajane potrzeby. Jednocześnie są zupełnie zwolnione z odpowiedzialności, ponieważ rodzice wyręczają je w wielu obowiązkach. Chociaż dzieci mają poczucie, że są kochane i akceptowane, to mają świadomość, że zajmują w rodzinie ważne miejsce, często nadmiernie wykorzystują zachowanie rodziców i nie osiągają samodzielności. Faktyczną władzę sprawują dzieci, a oddanie rodziców dochodzi niekiedy do takiego stopnia, że nie dbają o własną więź małżeńską ${ }^{28}$.

Członkowie takiego systemu rodzinnego są bardzo wrażliwi na punkcie uczuć. Komunikacja naznaczona jest wrażliwością i szacunkiem, często szybko dochodzi do kompromisu, aby uniknąć trudnych sytuacji. Z drugiej strony, taki system komunikacji często prowadzi do braku szczerości, ponieważ nadrzędnym celem jest bezkonfliktowość i unikanie trudnych tematów. Dzieje się tak ze względu na źle rozumianą lojalność. Członkowie rodziny odczuwają poczucie winy za poruszanie tematów, które mogą przyczynić się do zranienia innych ${ }^{29}$.

Małżeństwo rodziców jest zazwyczaj stabilne, ponieważ także między sobą unikają doprowadzania do sytuacji konfliktowych. Ich przystosowanie wiąże się często z poświęceniem własnych zobowiązań i potrzeb. Nie musi wynikać to z miłości do współmałżonka, ale staje się sposobem na uniknięcie poczucia winy, zyskania akceptacji

\footnotetext{
27 Por. M. Ryś, Odporność psychiczna..., s. 24-25.

28 Por. D. Field, Osobowości rodzinne..., s. 58-59; M. Ryś, Odporność psychiczna..., s. 24-25.

29 Por. A. Strzeszewska, System rodziny pochodzenia a poczucie własnej wartości i oczekiwania od małżństwa u młodych dorosłych, Kwartalnik Naukowy Fides et Ratio 3 (2014), s. 110.
} 
czy załagodzenia konfliktu. Uwaga małżonków nie skupia się na sobie wzajemnie, ale jest kierowana na dzieci. Osobą bardziej poświęcającą się dzieciom jest zazwyczaj matka; $z$ reguły z tego powodu jej relacja $\mathrm{z}$ mężem zostaje całkiem zaniedbana ${ }^{30}$.

W momentach kryzysowych członkowie rodziny nadopiekuńczej mogą liczyć na wzajemną pomoc i wsparcie. Może to być jednak utrudniane przez brak decyzyjności i pragnienie zadowolenia wszystkich. Dorosłe dzieci charakteryzują się często brakiem pewności siebie i zależnością od opinii i wskazań innych. Zauważalne są u nich zachowania zbliżające się do syndromu wyuczonej bezradności. Zazwyczaj bardzo późno opuszczają dom rodzinny, ponieważ odczuwają obawy przed rozpoczęciem samodzielnego życia, a także jest to im zwykle utrudniane przez samych rodziców, którzy ciągle odczuwają potrzebę ingerencji w ich życie. Po opuszczeniu domu rodzinnego, osoby z rodziny nadopiekuńczej doświadczają poczucia winy z powodu opuszczenia rodziców i braku poświęcania im pełnej uwagi. Silne poczucie przywiązania do rodziców i wdzięczność za okazywaną im troskę sprawia, że odczuwają rozdarcie emocjonalne pomiędzy chęcią lojalności wobec rodziców a potrzebą tworzenia więzi małżeńskiej i angażowania się w relacje ze współmałżonkiem. Często ta tendencja jest podtrzymywana przez samych rodziców. Może tu też pojawić się żal ze strony dzieci wobec rodziców, że nie zostały w pełni przygotowane na wyzwania dorosłego życia, gdyż nie potrafią poradzić sobie $\mathrm{z}$ egzystencjalnymi trudnościami ${ }^{31}$.

\subsection{Rodzina uwikłana}

W rodzinie uwikłanej zorientowanie członków rodziny na siebie oraz skoncentrowanie uwagi rodziców na dzieciach jest jeszcze silniejsze, niż w przypadku rodziny nadopiekuńczej. Najczęściej jest to powodowane problemami w relacji małżeńskiej. W tym modelu granice

\footnotetext{
30 Por. D. Field, Osobowości rodzinne..., s. 57-58; M. RYś, Odporność psychiczna..., s. 24-25.

31 Por. D. Field, Osobowości rodzinne..., s. 65-68.
} 
pomiędzy rodzicami a dziećmi nie istnieją, rodzice poszukują u dzieci emocjonalnego wsparcia i sojusznika przeciw współmałżonkowi. Poprzez przesadną bliskość naruszana jest prywatność dziecka ${ }^{32}$.

Małżonkowie odczuwają poczucie braku spełnienia w relacji ze sobą, jednak starają się nie okazywać tego na zewnątrz. Odnoszą się do siebie serdecznie, dobrze współdziałając przy wypełnianiu ról społecznych. Czują się zobowiązani do spełniania ogólnie przyjętych w społeczeństwie standardów. Brakuje jednak między nimi prawdziwej miłości i troski, a obawy przed porzuceniem prowadzą do zbliżenia się do dzieci i rozciągnięcia nad nimi nadmiernej kontroli ${ }^{33}$.

W rodzinie uwikłanej jej członkowie odczuwają poczucie nieustannego zagrożenia, dlatego dla zapewnienia sobie bezpieczeństwa dążą do uzależnienia od siebie wszystkich członków. Rodzice uważają, że zaspokajają potrzeby dzieci, jednak faktycznie czynią to dla siebie. Proces wychowawczy nacechowany jest manipulacją i wywoływaniem poczucia winy, dlatego dziecko uczy się rezygnować z własnej indywidualności i skupiać się na pragnieniach i oczekiwaniach rodziców ${ }^{34}$.

Na pierwszym miejscu stawiane jest wspólne życie rodzinne, przez co członkowie rodziny uwikłanej mają zazwyczaj trudności z wchodzeniem w relacje z innymi osobami. W dorosłości dzieci mają problem z prowadzeniem niezależnego życia. Często pozostają pod presją psychicznej kontroli ze strony rodziców. Mają problem z opuszczeniem domu rodzinnego, cały czas są manipulowane przez rodziców, a podejmowane przez nie decyzje kwestionowane pod względem słuszności. Osoby wychowywane w takim systemie rodzinnym zazwyczaj szukają partnera o silnej osobowości, który z jednej strony pomoże uwolnić się od zaborczych rodziców, a z drugiej przejmie ich rolę w życiu małżeńskim. Zdarza się, że złość rodziców jest wówczas

\footnotetext{
32 Por. TAmże, s. 79-84; A. Strzeszewska, System rodziny..., s. 110-111.

33 Por. M. RYś, Odporność psychiczna..., s. 25-27.

34 Por. D. Field, Osobowości rodzinne..., s. 87.
} 
kierowana przeciwko współmałżonkowi, który jest obwiniany o odciąganie dziecka od rodziny pochodzenia ${ }^{35}$.

\subsection{Rodzina prawidłowa}

W rodzinie prawidłowej istnieje wysoki stopień indywidualności jej członków, a jednocześnie dobre relacje z innymi. Granice między rodzicami a dziećmi są zachowane, jednak nie w sposób sztywny, aby umożliwić nawiązanie prawidłowych więzi. Władzę w rodzinie sprawują rodzice, którzy są dla siebie równorzędnymi partnerami. Szanują prawa i uczucia własne oraz dzieci. Ustanawiają jasne reguły i zasady postępowania, stosowne do wieku i poziomu rozwoju dzieci. W ten sposób zaspokojona zostaje potrzeba bezpieczeństwa i nieograniczona zostaje możliwość rozwoju ${ }^{36}$.

Małżonkowie okazują sobie wzajemnie szacunek i troskę. Są świadomi, że ich małżeństwo stanowi podstawę rodziny. Potrafią radzić sobie w sytuacji kryzysu, poszukują prawidłowych rozwiązań i są zdolni do kompromisu. Umiejętność komunikowania się oraz silna więź między małżonkami stanowią wzór, który w przyszłości jest wykorzystywany przez dzieci ${ }^{37}$.

Najczęściej stosowanymi metodami wychowawczymi są rozmowa i łagodna perswazja. Rodzice nie dopuszczają do manipulowania sobą przez dzieci. W sytuacji nieposłuszeństwa stosują kary, które są sprawiedliwe i adekwatne do stopnia winy. Potrafią w mądry sposób towarzyszyć swoim dzieciom i udzielać im rad, jednak pozwalają im na samodzielne podejmowanie decyzji, ucząc je odpowiedzialności i ponoszenia konsekwencji za swoje wybory. Szanują i przyjmują odrębne zdanie dzieci, co powoduje ukształtowanie poczucia realnego wpływu na to, co się dzieje. Jednocześnie autorytet rodziców nie jest

35 Por. TAMżE, s. 90-92.

36 Por. J. Wolińska, Obraz rodziny generacyjnej w percepcji samotnych matek, Horyzonty Psychologii 6 (2016), s. 48-49.

37 Por. M. Ryś, Odporność psychiczna..., s. 19-21; D. Field, Osobowości rodzinne..., s. 34-35. 
kwestionowany, ale nie mają obawy przed utratą miłości i akceptacji ze strony dzieci ${ }^{38}$.

Członkowie rodziny prawidłowej są nastawieni na wzajemną komunikację i aktywne słuchanie. Nie narzucają nikomu swojej wizji rozwiązania problemu. Zdarza się, że pojawiają się problemy wychowawcze, jednak najczęściej mają one charakter przejściowy, a rodzina wkłada wspólny wysiłek w ich rozwiązanie. Członkowie rodziny chętnie i często spędzają ze sobą czas. Dzieci dorastające w rodzinie prawidłowej cechują się wysoko rozwiniętym poczuciem własnej wartości, samodzielnością, nie przejawiają obaw przed odrzuceniem. Ich odejściu $\mathrm{z}$ domu może towarzyszyć smutek, jednak jest to reakcja naturalna, nie zostaje wzbudzone poczucie winy. Usamodzielnienie się dzieci jest traktowane jako naturalny i pożądany etap życia. Dorosłe dzieci chętnie zwracają się do rodziców o radę bądź pomoc, ponieważ wiedzą, że zostanie im udzielona w sposób niezaburzający systemu stworzonej przez nich rodziny. Zostaje utrzymany zdrowy dystans, który pozwala na partnerskie relacje ${ }^{39}$.

\section{Zakończenie}

W procesach kościelnych niewątpliwie często pojawia się kategoria osobowości niedojrzałej, która rzutuje na trwałość małżeństwa, niejednokrotnie czyniąc osobę niezdolną do zawarcia małżeństwa. W wielu sprawach tego typu osobowość jest generowana dysfunkcjonalną atmosferą rodziny pochodzenia ${ }^{40}$ : przykładem czego może być występowanie syndromu dorosłych dzieci alkoholików (DDA) ${ }^{41}$.

\footnotetext{
38 Por. TAmże, s. 35-38.

39 Por. TAMżE, s. 38-41.

40 Por. M.P. Hilbert, Classificazione delle patologie psiche di tipo paranoide: analisi strutturale e giurisprudenza rotale di merito, Periodica 86 (1997), s. 138; S. Kosowicz, Niezdolność do relacji międzyosobowych (studium w oparciu o wyroki rotalne okresu posoborowego), Radom 1988, s. 118.

41 Szerzej na ten temat: A. Ży wicA, Syndrom dorosłych dzieci alkoholików (DDA), w: G. DzIerżon (red.), Wybrane zagadnienia z tematyki wplywu alkoholizmu na
} 
Gdy rodzina ma niekorzystny wpływ na kształtowanie się osobowości dziecka, wówczas sprzyja to również powstawaniu u niego różnych zaburzeń zachowania. Dysfunkcjonalna rodzina nie spełnia przypisanej sobie funkcji socjalizującej, przez co nie przekazuje dziecku pozytywnych norm, zwyczajów oraz wartości danego społeczeństwa. Opisany stan wiąże się również z niemożliwością zapewnienia poczucia bezpieczeństwa, wymiany uczuć, osiągnięcia równowagi emocjonalnej oraz właściwego rozwoju osobowości.

W tym miejscu jednak należałoby poczynić pewną dygresję, mianowicie w analizie relacji pomiędzy rodziną a dzieckiem, w myśleniu zdecydowanie trzeba wykluczyć determinizm, w tym sensie, że gdy rodzina jest dysfunkcjonalna, to dziecko na pewno będzie posiadało zaburzoną osobowość. Takie postrzeganie byłoby sprzeczne z chrześcijańską wizją antropologiczną eksponującą ludzką wolność decyzyjną. Niemniej jednak realnie nie można wykluczyć wystąpienia zaburzonej osobowości.

Stąd też w procesach o stwierdzenie nieważności małżeństwa nie można posługiwać się jakimś szablonem; każdy bowiem kazus powinien zostać oceniony odrębnie. Jeśli pojawiłby się problem z niezdolnością konsensualną, to kwalifikacja czy sprawę należałoby prowadzić z tytułu niezdolności do podjęcia istotnych obowiązków małżeńskich (kan. 1095, n. 3 KPK/83), czy też z poważnego braku rozeznania oceniającego, byłaby uzależniona od okoliczności sprawy.

Wykazanie i udowodnienie osobowości niedojrzałej nie jest sprawą łatwą. Każdy taki przypadek musi zostać wnikliwie oceniony, w tym sensie czy cechy i zachowania przejawiane przez daną osobę rzeczywiście uniemożliwiają, czy jedynie utrudniają podjęcie i wypełnienie istotnych obowiązków małżeńskich.

niezdolność do zawarcia małżéstwa (syndrom DDA, Zespół Kosakowa, AA), Kraków 2018, s. 63-92. 


\section{References}

FIELd D., Osobowości rodzinne. Zrozumienie korzeni swojej osobowości kluczem do zrozumienia siebie i innych, Warszawa 1999.

GoŁęBIOwska A., Osobowość niedojrzała jako podstawa orzeczenia nieważności małżeństwa w świetle wyroków Roty Rzymskiej i trybunałów kościelnych, Prawo Kanoniczne 55 (2012), s. 57-86.

Graczy K K., Dowodzenie nieważności małżeństwa z tytułu poważnego braku rozeznania oceniajacego i z tytułu niezdolności do podjęcia $i$ wypetnienia istotnych obowiązków małżeńskich, Studia Wrocławskie 18 (2016), s. 253-274.

Guiry R.W., Immaturity, Maturity, and Christian Marriage, Studia Canonica, 25 (1991), s. 93-114.

Hilbert M.P., Classificazione delle patologie psiche di tipo paranoide: analisi strutturale e giurisprudenza rotale di merito, Periodica 86 (1997), s. 125-144.

Kosowicz S., Niezdolność do relacji międzyosobowych (studium w oparciu o wyroki rotalne okresu posoborowego), Radom 1988.

LeszCZyŃski G., Niedojrzałość emocjonalna a wykluczenie dobra matżonków, Ius Matrimoniale 7 (2002), s. 87-110.

Malecha P., Polski wymiar sprawiedliwości widziany przez pryzmat Sygnatury Apostolskiej, w: T. Rozkrut (red.), Orzecznictwo rotalne w praktyce sadowej Kościoła, Tarnów 2010, s. 11-49.

Mendonca A., The Effects of Personality Disorders on Matrimonial Consent, Studia Canonica 21 (1987), s. 67-104.

Michaelson V., Pickett W., King N., Davison C., Testing the theory of holism: A study of family systems and adolescent health, Preventive Medicine Reports 4 (2016), 313-319.

Prężyna W., Problem psychologicznych kryteriów niezdolności do podjęcia i wypetnienia zobowiązań małżeńskich, w: J. KRUKowski (red.), Kościół i Prawo, t. 6, Lublin 1988, s. 103-114.

Przy вує I., Obraz matki i ojca a identyfikacja adolescentów z rodzicami, Roczniki Socjologii Rodziny 17 (2016), s. 47-64.

Ryś M., Odporność psychiczna osób wzrastajacych w różnych systemach rodzinnych, Warszawa 2016.

Ryś M., Systemy rodzinne. Metody badań struktury rodziny pochodzenia i rodziny własnej, Warszawa 2004.

SobAŃski R., Wyrok Sądu Metropolitalnego w Katowicach z 29.12.2005 z tytułu niezdolności - z racji psychicznych - powoda do podjęcia istotnych obowiązków małżeńskich, Ius Matrimoniale 11 (2006), s. 179-184.

STACHYRA J., Wpływ rodziny na kształtowanie się osobowości dziecka, Sympozjum 2 (2000), s. 85-104. 
Strzeszewska A., System rodziny pochodzenia a poczucie własnej wartości i oczekiwania od matżeństwa u młodych dorostych, Kwartalnik Naukowy Fides et Ratio 3 (2014), s. 105-128.

SZTychmiler R., Znaczenie osobowości kandydata do małżeństwa w świetle obowiązującego prawa kanonicznego, Prawo Kanoniczne 40 (1997), s. 201-217.

Wolińska J., Obraz rodziny generacyjnej w percepcji samotnych matek, Horyzonty Psychologii 6 (2016), s. 45-73.

Ziemska M., Postawy rodzicielskie, Warszawa 1973.

Żywica A., Syndrom dorostych dzieci alkoholików (DDA), w: G. Dzierżon (red.), Wybrane zagadnienia z tematyki wplywu alkoholizmu na niezdolność do zawarcia małżeństwa (syndrom DDA, Zespót Kosakowa, AA), Kraków 2018, s. 63-92.

\section{Nota o autorze}

Emilia Zyskowska - magister licencjat prawa kanonicznego, biegła psycholog przy Sądzie Metropolitalnym Warszawskim. 